\title{
Studies On Invitro Analysis Of Sargassum Wightii Against Human Simplex Virus (HSV)
}

\author{
Akila $^{1}$, Anitha C. ${ }^{1}$, Pratheeba J. $^{2}$, Sumanth Kumar B. ${ }^{2}$ \\ ${ }^{I}$ Assistant Professor, Department of Microbiology, Meenakshi Medical College Hospital and Research Institute, \\ Enathur, Kanchipuram, Tamilnadu, India, ${ }^{2}$ Assistant Professor, Department of Biochemistry, Meenakshi Medical \\ College Hospital and Research Institute, Enathur, Kanchipuram, Tamilnadu, India
}

\begin{abstract}
Introduction: Human simplex viruses are ulcerative diseased found in skin and genital organs depending upon the strain. It affects an individual at least once in a lifetime by direct contact with an infected person. There are two strains of HSV predominantly found are HSV-1 and HSV-2. HSV-1 infects the pharynx and oral region, whereas HSV-2 infects the genital areas of sexual contact.

Materials and Method: The crude extract of S. wightii on the proliferation of Vero cells was assessed by the neutral dye uptake method. Various fold of serially diluted solvent crude extracts showed cytotoxic concentration $_{50}\left(\mathrm{CC}_{50}\right)$ at 750 and $500 \mu \mathrm{g} / \mathrm{mL}$ of ethyl acetate and methanol extract, respectively.

Results: The Antiviral activity of solvent crude extract against HSV-1 showed significant reduction of virus on Vero cells. Among the solvent crude tested, the ethyl acetate showed effective $\mathrm{IC}_{50}$ against HSV-1 at 300 $\mu \mathrm{g} / \mathrm{mL}$.

Conclusion: The seaweed $S$. wightii is a natural source in treating the pathogen HSV-1 and it clearly indicated that, the marine brown algae $S$. wightii possess strong antiviral activity with slight cytotoxic effect.
\end{abstract}

Keywords: Sargassum wightii, HSV-1, Antiviral activity, Octyl butyl phthalate, Neutral dye.

\section{Introduction}

Marine resources are abundant and most of them are not explored due to its vast environmental conditions and growth patterns. A country like India is diversified with a long coastline of about $7500 \mathrm{~km}$ with high amount of seaweed population ${ }^{[1]}$. The habitat of macroalgae in the marine environment is present along the coastline, embedded with rocks having high nutrients, immersed in the sea water at great depths. Depending upon the nature's pattern seaweed produces numerous active compounds ${ }^{[11]}$ which are very much useful for the

\section{Corresponding Author:}

Akila

Assistant Professor, Department of Microbiology, Meenakshi Medical College Hospital and Research Institute, Enathur, Kanchipuram, Tamilnadu, India e-mail: akila@mmchri.ac.in mankind. The active ingredients obtained from the seaweed helps the society to have a healthy life against harmful pathogens and enrich the field of Pharmacology in producing new drugs ${ }^{[2]}$.

Herpes simplex virus (HSV) is a communicable virus which transmits from person to person. Our studies focus on HSV-1 which affects the oral and pharyngeal regions of the population. It affects almost all the people irrespective of any age from neonatal to old age people. The structure of HSV-1 consists of ds DNA, Capsid, Capsomeres and tegument and type 1 belongs to $\alpha$-HSV. Viruses are manifested in epithelial cells and then spreads to the sensory nerves and finally produces cutaneous lesions ${ }^{[3]}$. The symptoms with HSV1 patients are mouth sores, tingling, itching and oral sex. Patients with HIV, Cancer, AIDS, transplantation performed, patients, when infected with HSV it may cause serious effect such as inflammation in the brain, eye infection, and even deaths can happen ${ }^{[4]}$. The HSV- 
1 is easily prevented by avoiding direct contact with infected persons, sharing their utensils; avoid kissing or oral sex and frequent hand wash. In newborn infants of about 10,000 births, 10 babies are infected with HSV-1 as per the WHO report. This infection in babies causes nerve problem and even death when passed from mother to fetus ${ }^{[5]}$.

The seaweed Sargassum wightii belongs to a Pheophyceae family ${ }^{[6,12]}$ and abundantly found in warm and temperate climate ${ }^{[7]}$. In India, it is distributed in Maharashtra, Goa, Kerala and Tamil Nadu. In Tamil $\mathrm{Nadu}$, it is found along the coastline of Kovalam, Rameswaram, Mandabam areas. The macroalgae S.wightii is rich in alginic acid, which is a commercial product. The macroalgae is rich in secondary metabolites and these are helpful in synthesizing pharmaceutical products (Subash et al., 2014). Thus the present work aimed at treating the HSV-1 strain with the macroalgae as a biological method and it is cost effective in nature.

\section{Material and Method}

Study area and Extraction process: The seaweeds were collected from Coastal line of Mandapam, Ramanathapuram District, Tamil Nadu, India and was identified as Sargassum wightii by the phycologist expertal committee and sample were washed in tap water followed by distilled water and shade dried at room temperature. The dried sample was powdered using mechanical blender and extracted using mid polar to polar solvents i.e. Ethyl acetate and methanol. The sample was filtered and condensed using rotary evaporator and stored till further use ${ }^{[8]}$.

Cells and viruses: Vero E6 cells were cultured and maintained in Eagles Minimum Essential Medium (EMEM) with $10 \%$ fetal calf serum (heat inactivated) and antibiotics like penicillin and streptomycin $100 \mu \mathrm{g} /$ $\mathrm{ml} \mathrm{kept} \mathrm{in} \mathrm{incubator} \mathrm{at} 37^{\circ} \mathrm{C}$ with optimal conditions like $\mathrm{CO}_{2}$ and humidity. $\mathrm{HSV}-1$ stocks were proliferated Invero $\mathrm{E} 6$ cells and stored at $-20^{\circ} \mathrm{C}$ till further use.

Cytotoxicity Study: Seaweed S.wighti i crude extract was proliferated on Vero E6 cells by the neutral dye uptake method in 96 well plates by the method of Rajabhandari et al., $2009{ }^{[9]}$.

Antiviral activity of crude extract of S.wightii: Vero E6 cells were seeded in 96 well plates in $100 \mu 1$ of the EMEM medium by serial dilution technique in four different replicas for a time period of $24 \mathrm{~h}$. Once the cells were infected with $30 \mu \mathrm{l}$ of HSV-1 strain, TCID $_{50}$ was incubated at $37^{\circ} \mathrm{C}$ for 3 days i.e. $72 \mathrm{~h}$. Control samples were also maintained without viral strain and antibiotic act as positive control. sulforhodamine B assay (SRB) was used to determine the viability of cells by showing absorbance at $540 \mathrm{~nm}$ and percentage was calculated.

\section{Results and Discussion}

The Crude Extract Yield: The Sargassum wightii sample was shade dried and powdered. The powdered sample was extracted and condensed using a Soxhlet apparatus. The percentage of the crude extract yield was $4.7 \pm 0.27$ in ethyl acetate and $2.6 \pm 0.54$ in methanol solvent. From the obtained yield in the crude extract sample showed a good amount of yield in ethyl acetate mid polar solvent compared to high polar solvent Methanol.

In-vitro Antiviral Activity of $S$. wightii Solvent Crude Extracts: Various fold of serially diluted solvent crude extracts results as showed in (Graph 1). Cytotoxic concentration $_{50}\left(\mathrm{CC}_{50}\right)$ of the solvent crude showed 750 and $500 \mu \mathrm{g} / \mathrm{ml}$ of ethyl acetate and methanol, respectively. The Antiviral activity of solvent crude extract against HSV-1 showed significant reduction of virus on Vero cells. Among the solvent crude tested, the ethyl acetate showed effective $\mathrm{IC}_{50}$ against HSV-1 at $300 \mu \mathrm{g} / \mathrm{ml}$, while methanol extract showed at $500 \mu \mathrm{g} /$ $\mathrm{ml}$ (Graph 2).

The reduction of HSV in the tested samples is due to the narrow action against HSV-1 than the Vero cells. Brown macroalgae, is rich in compounds like phlorotannins which have been analyzed to have anti$\mathrm{HIV}^{[13]}$ and anti-HSV activity ${ }^{[10]}$. 


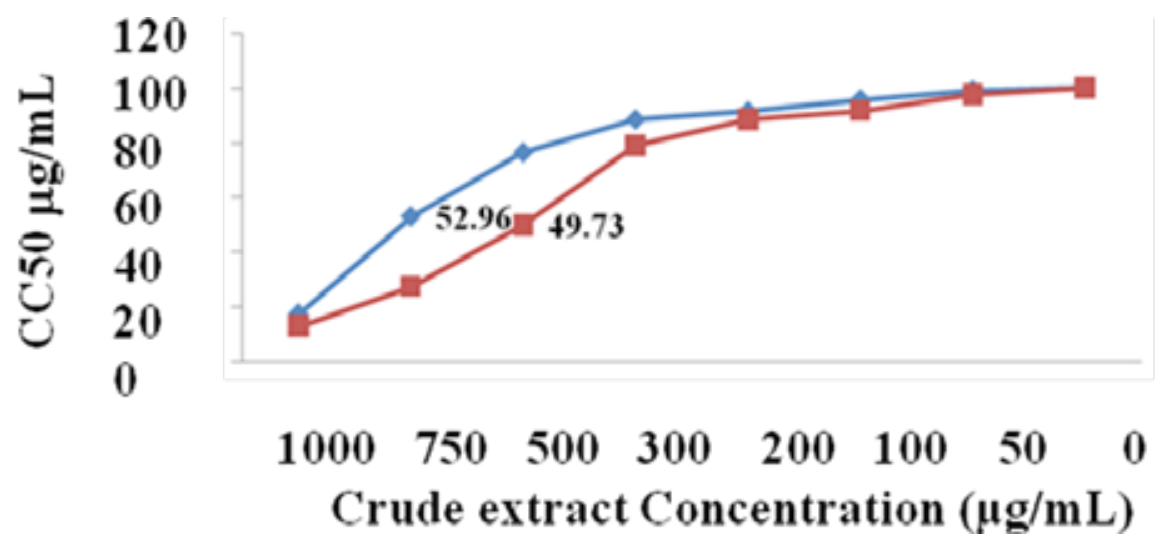

Graph 1: Cytotoxic concentration ${ }_{50}$ of solvent crude extracts of $S$. wightii

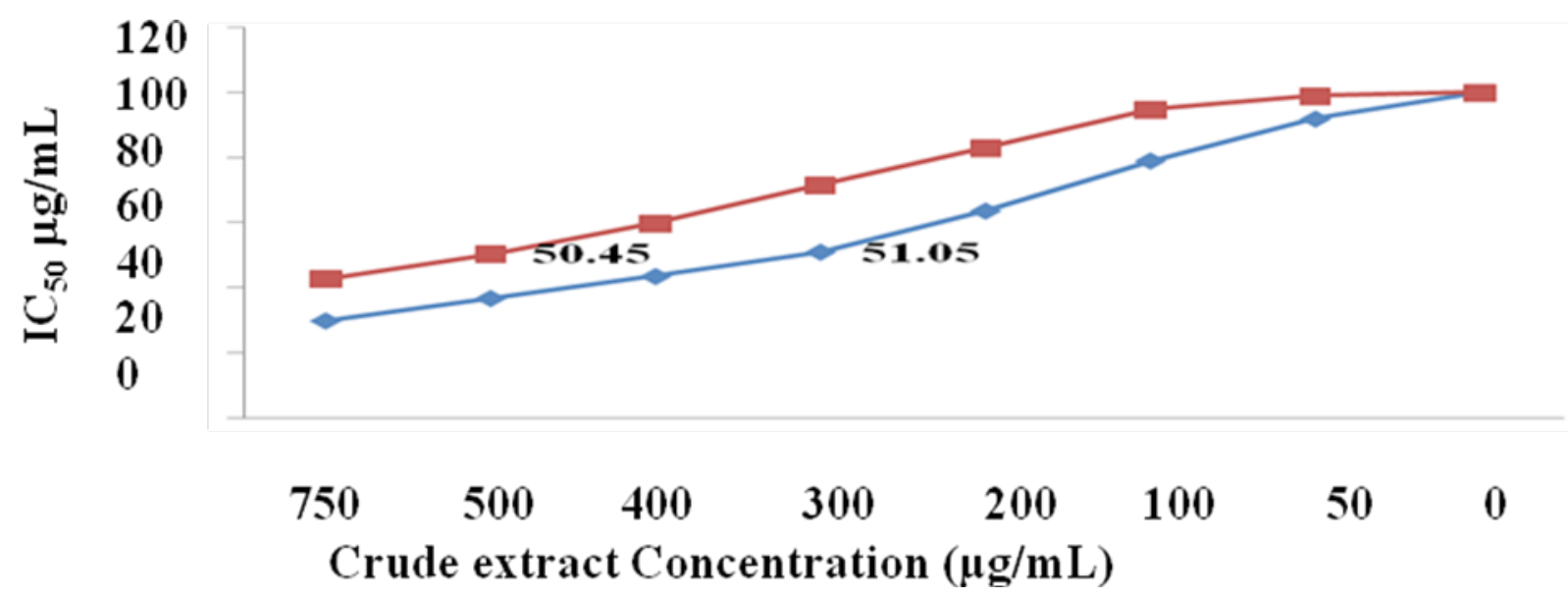

Graph 2: Antiviral activity of crude extracts on $\mathrm{IC}_{50}$ against $\mathrm{HSV}-1$

\section{Conclusion}

The present study preliminarily focused on a crude ethyl acetate extract of Sargassum wightii is a suitable macro algae for the production of new drugs against HSV-1 due to the presence of the secondary metabolites $^{[14,15]}$. Further studies are purified of the crude extract and Invivo studies can be performed to identify the extract drug for HSV-1.

Ethical Clearance: Nil

Source of Funding: Meenakshi Academy of Higher Education and Research, Chennai, India

Conflict of Interest: Nil

\section{References}

1. Pandithurai M, Murugesan S, Sivamurugan V, Thamizh SN. Antifungal activity of various solvent extracts of marine brown alga Spatoglossum asperum. Int J Pharm Chem. 2015;5:277-80.
2. Chanda S, Dave R, Kaneria M, Nagani K. Seaweeds: a novel, untapped source of drugs from sea to combat infectious diseases. Current research, technology and education topics in applied microbiology and microbial biotechnology. 2010;1:473-80.

3. Watson AM, Prasad KM, Klei L, Wood JA, Yolken RH, Gur RC, Bradford LD, Calkins ME, Richard J, Edwards N, Savage RM. Persistent infection with neurotropic herpes viruses and cognitive impairment. Psychological medicine. 2013 May;43(5):1023-31.

4. Abu-Jafar A, Huleihel M. Antiviral activity of Eucalyptus camaldulensis leaves ethanolic extract on herpes viruses infection. Int. J. Clin. Virol. 2017;1:1-9.

5. https://www.who.int/news-room/fact-sheets/detail/ herpes-simplex-virus.2020.

6. Pillay KS, Varier NS. Seaweed resources of Travancore-Cochin. Proc. 1 Int. Seaweed Sym.. 1952:101. 
7. Tseng CK. East Asiatic species of Sargassum subgenus Bactrophycus J. Agardh (Sargassaceae, Fucales), with keys to the sections and species. Taxonomy of Economic Seaweeds; California Sea Grant College Program. 1985:1-5.

8. Yende SR, Harle UN, Chaugule BB. Therapeutic potential and health benefits of Sargassum species. Pharmacognosy reviews. 2014 Jan;8(15):1.

9. Rajbhandari M, Mentel R, Jha PK, Chaudhary RP, Bhattarai S, Gewali MB, Karmacharya N, Hipper M, Lindequist U. Antiviral activity of some plants used in Nepalese traditional medicine. EvidenceBased Complementary and Alternative Medicine. 2009 Dec 1;6.

10. Singh IP, Bharate SB. Phloroglucinol compounds of natural origin. Natural product reports. 2006;23(4):558-91.

11. Fayaz M, Namitha KK, Murthy KC, Swamy MM, Sarada R, Khanam S, Subbarao PV, Ravishankar GA. Chemical composition, iron bioavailability, and antioxidant activity of Kappaphycus alvarezzi
(Doty). Journal of agricultural and food chemistry. 2005 Feb 9;53(3):792-7.

12. Varrier, NS. and Pillai, KS. 1951. Studies on marine products. Part II, Optimum conditions for the largescale extraction of alginic acid from Sargassum. Seaweeds of Cape Comorin. Bull. Cent. Res. Inst. Univ. Travancore 2: 23-62.

13. Artan M, Li Y, Karadeniz F, Lee SH, Kim MM, Kim SK. Anti-HIV-1 activity of phloroglucinol derivative, 6, 6'-bieckol, from Ecklonia cava. Bioorganic \& Medicinal Chemistry. 2008 Sep 1;16(17):7921-6.

14. Smit AJ. Medicinal and pharmaceutical uses of seaweed natural products: a review. Journal of applied phycology. 2004 Aug 1;16(4):245-62.

15. Bocanegra A, Bastida S, Benedí J, Rodenas S, Sanchez-Muniz FJ. Characteristics and nutritional and cardiovascular-health properties of seaweeds. Journal of medicinal food. 2009 Apr 1;12(2):23658. 